\title{
Influence of Soil Saturation and Temperature on Erwinia chrysanthemi Soft Rot of Carrot
}

\author{
J. J. Farrar, Department of Plant Pathology, University of California, Davis 95616; J. J. Nunez, University of \\ California Cooperative Extension, Kern County; and R. M. Davis, Department of Plant Pathology, University of \\ California, Davis
}

\begin{abstract}
Farrar, J. J., Nunez, J. J., and Davis, R. M. 2000. Influence of soil saturation and temperature on Erwinia chrysanthemi soft rot of carrot. Plant Dis. 84:665-668.

In 1998, soft rot caused by Erwinia chrysanthemi resulted in an estimated loss of 1,800 tons of carrots in California. The disease appeared to be related to unusually high temperatures and excessive irrigation. To determine the optimum conditions for development of soft rot under controlled conditions, pots of carrots inoculated with E. chrysanthemi were saturated with water and incubated at $20,25,30$, or $35^{\circ} \mathrm{C}$. Plants were harvested and examined for disease $12,24,36$, 48,72 , and $96 \mathrm{~h}$ after inoculation. Negligible disease occurred after $12 \mathrm{~h}$. Disease severity and incidence increased with increasing temperature and duration of saturation from 24 to $96 \mathrm{~h}$. In a second experiment, carrot disks were inoculated with three isolates each of E. chrysanthemi and E. carotovora subsp. carotovora and incubated at $15,20,25,30$, and $35^{\circ} \mathrm{C}$. After $48 \mathrm{~h}$, the disks were washed to remove rotted tissue and reweighed. Neither bacterium reduced carrot disk weight at $15^{\circ} \mathrm{C}$. In general, moderate weight reduction occurred at 20 and $25^{\circ} \mathrm{C}$. The greatest degree of soft rot was caused by E. chrysanthemi at 30 and $35^{\circ} \mathrm{C}$. E. carotovora subsp. carotovora isolates were relatively less virulent than $E$. chrysanthemi at $30^{\circ} \mathrm{C}$ and none of the $E$. carotovora subsp. carotovora isolates reduced carrot disk weight at $35^{\circ} \mathrm{C}$. This is the first report of E. chrysanthemi causing soft rot of carrot in California. Based on these results, growers should limit the length of time carrot roots are exposed to saturated soil, especially at high soil temperatures.
\end{abstract}

In August through October, 1998, a high incidence of soft rot occurred in carrot fields in Madera, Kern, and Imperial Counties, California. Numerous truckloads of harvested carrots were discarded and some fields were abandoned when the incidence of disease reached $25 \%$ or more. An estimated 1,800 tons of carrots were lost during this period. Soft rot lesions were pale orange, circular, 5 to $15 \mathrm{~mm}$ in diameter, and soft to the touch. There were multiple lesions per carrot root and some lesions coalesced to form large, irregular rotted areas. When infected carrots were washed at the packing sheds, soft rotted tissue was removed, creating craters in the carrots, resulting in an unmarketable product. It was hypothesized that high soil temperatures were associated with the high incidence of soft rot. Data from a CIMIS weather station maintained at the University of California Cotton Research Station, Shafter, CA, revealed that average daily maximum soil temperatures at a depth of $15 \mathrm{~cm}$ in August and September, 1998, were 28.9 and $26.6^{\circ} \mathrm{C}$, respectively. These

Corresponding author: R. M. Davis

E-mail: rmdavis@ucdavis.edu

Accepted for publication 29 February 2000.

Publication no. D-2000-0414-01R

(C) 2000 The American Phytopathological Society averages are 2.2 and $2.4^{\circ} \mathrm{C}$ higher, respectively, than the averages for the previous 10 years in the San Joaquin Valley.

Little information is available on soft rot of carrot. Erwinia carotovora subsp. carotovora was identified as the causal agent of carrot soft rot in India (12) and Korea (2) after severe disease outbreaks. In Texas, both E. chrysanthemi and E. carotovora subsp. carotovora caused core rot of carrots in the field (16). In stored carrots, infection by E. carotovora increased with increasing storage temperatures up to $24^{\circ} \mathrm{C}$, but declined rapidly at higher temperatures (9). High relative humidity during storage and wounding prior to storage also resulted in higher infection rates. In Florida, the addition of chlorine to wash water and chilling was found to significantly reduce carrot soft rot in storage (14). The goals of this study were to determine the cause of the epidemic in California in 1998 and examine the influence of temperature and soil saturation on its development.

\section{MATERIALS AND METHODS}

Isolation and identification of isolates. Culled carrots with visible soft rot were obtained from packing sheds in Kern County. Cultures of bacteria were obtained by streaking a loopful of soft carrot tissue directly onto Miller-Schroth media (10). Orange-red colonies were transferred to yeast-dextrose-carbonate (YDC) agar after the plates were incubated for 2 to 3 days in a $28^{\circ} \mathrm{C}$ incubator. Eleven isolates from five fields were identified by a profile for utilization of 95 carbon sources (Biolog GN Micro Plates, Hayward, CA), fatty acid methyl ester analysis (MIDI Microbial Identification System version 3.8, Newark $\mathrm{DE})$, gram determination $(3 \% \mathrm{KOH}$ string test; 15), ability to soft rot potato disks, acid production from palatinose, methyl $\alpha$ D-glucopyranoside, and trehalose, utilization of malonate, and phosphatase production (4). Three isolates were tested for erythromycin sensitivity. To test the ability of the isolates to cause soft rot, carrot disks were inoculated with seven isolates. Carrots were surface sterilized for $30 \mathrm{~min}$ in $0.525 \%$ sodium hypochlorite, rinsed with deionized water, and cut into disks with a sterilized knife. A loop of bacteria from a 24-h culture grown on YDC at room temperature was streaked onto the carrot disks. Sterile water was used as a control. Four disks were inoculated with each isolate. All disks were incubated in a plastic box lined with moist paper towels for 2 days at room temperature $\left(19\right.$ to $\left.21^{\circ} \mathrm{C}\right)$. Bacteria were then reisolated and reidentified as described above. In addition, six whole carrots were inoculated with each isolate. In these tests, carrots were surface sterilized, wounded by nicking the carrot with a sterilized scalpel, and inoculated with $10 \mu \mathrm{l}$ of a $10^{8} \mathrm{CFU} / \mathrm{ml}$ suspension. The concentration of the bacteria was determined by suspending a loopful of bacteria in sterile distilled water and adjusting the percentage transmittance at $500 \mathrm{~nm}$ to $20 \%$ on a spectrophotometer (Sequoia-Turner Model 340, Mountain View, CA). Sterile water was used as a control. Carrots were incubated in a plastic box lined with moist paper towels for 2 days at room temperature (19 to $21^{\circ} \mathrm{C}$ ). Bacteria were then reisolated as described above.

Effect of temperature and soil saturation duration on soft rot caused by $E$. chrysanthemi. Carrot cv. Caro-Pak was planted in a potting mix (peat moss: vermiculite, 1:1) in 11-cm-diameter styrofoam cups (Dart Container Corp, Mason, MI) with four drain holes. Seedlings were thinned to 4 to 5 per cup at the three-trueleaf stage. Carrots were watered daily with deionized water and fertilized weekly with a dilute complete nutrient solution. When the carrot roots were 10 to $12 \mathrm{~cm}$ long and 1.5 to $2 \mathrm{~cm}$ wide at the shoulder, the cups 
were placed inside new cups, moved to 20 , equilibrate for $12 \mathrm{~h}$. Six cups were placed in each water bath for each replication. Following the addition of $20 \mathrm{ml}$ of a $10^{8}$ $\mathrm{CFU} / \mathrm{ml}$ suspension of $E$. chrysanthemi to the top of each cup, the cups were saturated with deionized water. Water was added as necessary to the water baths to maintain the original water level and to cups to maintain saturation of the potting mix. Controls for each temperature were saturated, noninoculated cups and cups inoculated with $E$. chrysanthemi but not saturated. Root zone temperatures in the cups in the $20,25,30$, and $35^{\circ} \mathrm{C}$ water baths were $20,25,29$, and $33^{\circ} \mathrm{C}$, respectively. One cup from each bath was removed $12,24,36,48,72$, or $96 \mathrm{~h}$ after inoculation. At each sampling time, carrot roots were removed from the cups, rinsed, and rated for degree of infection using a pretransformed scale where $0=0 \%, 1=1$ to $7 \%, 2=8$ to $25 \%, 3=26$ to $50 \%, 4=51$ to $75 \%, 5=76$ to $93 \%$, and $6=94$ to $100 \%$ of the root surface with soft rot lesions. The average rating of all carrots in a cup was used in the data analysis. Each treatment consisted of three replications in time. The experiment was performed three times and the data combined. Data were analyzed with the analysis of variance (ANOVA) and REG procedures of SAS (SAS Institute, Cary, NC) and regression lines were compared with the REGR procedure of MSTAT-C (Michigan Statistics Group, East Lansing, MI).

Comparison of soft rot ability of $E$. chrysanthemi and $E$. carotovora subsp. carotovora. The ability of three isolates each of E. chrysanthemi and E. carotovora subsp. carotovora to cause soft rot of carrots at $15,20,25,30$, and $35^{\circ} \mathrm{C}$ was examined. Mature Caro-Pak carrots, har25,30 , or $35^{\circ} \mathrm{C}$ water baths, and allowed to

vested from a commercial field, were washed in running water, surface sterilized in $0.525 \%$ sodium hypochlorite for $30 \mathrm{~min}$, rinsed with deionized water, and cut into disks with a sterilized knife. A small core, $4 \mathrm{~mm}$ in diameter and 2 to $3 \mathrm{~mm}$ deep, was removed from the center of each carrot disk with a flamed cork borer. Disks were then weighed and placed on damp paper towels in plastic boxes. A 50- $\mu$ l aliquot of a $10^{8} \mathrm{CFU} / \mathrm{ml}$ suspension of each isolate from 24-h cultures on YDC was placed in the well in each carrot disk. Controls were inoculated with $50 \mu \mathrm{l}$ of sterile deionized water. Disks from each carrot were inoculated with each isolate and the control. The plastic boxes were placed in $15,20,25,30$, or $35^{\circ} \mathrm{C}$ incubators. After $48 \mathrm{~h}$, the soft, rotted portion of each disk was washed out under running water. Disks were weighed again and the difference between initial and final weights calculated. This difference, the amount of carrot tissue consumed by the bacteria, was analyzed using the SAS ANOVA procedure. The experiment was performed three times and the data combined.

\section{RESULTS}

Isolation and identification of isolates. E. chrysanthemi was identified from all affected carrots based on the physiological tests: gram negative; soft rot of potato disks; utilization of malonate; positive for phosphatase production; sensitive to erythromycin; and negative for acid production from palatinose, glucopyranoside, and trehalose. The identity of E. chrysanthemi was confirmed by FAME analysis (similarity index 0.881 to 0.923 ) and the Biolog test (similarity index 0.623 to 0.808 ). Carrot disks and wounded whole carrots inoculated with E. chrysanthemi developed soft rot, whereas the controls did not.

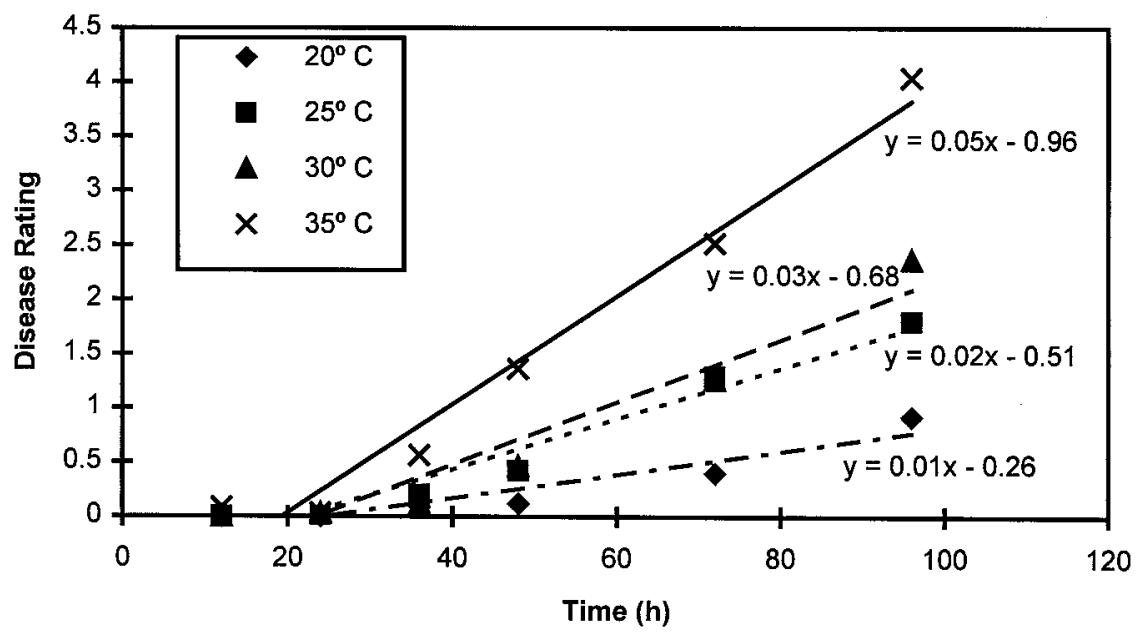

Fig. 1. Influence of temperature and duration of soil saturation on soft rot of carrots. Carrots were grown in 11-cm-diameter styrofoam cups and were 10 to $12 \mathrm{~cm}$ long and 1.5 to $2 \mathrm{~cm}$ wide at the shoulder when inoculated. Severity of soft rot was estimated using a pretransformed scale where $0=$ $0 \%, 1=1$ to $7 \%, 2=8$ to $25 \%, 3=26$ to $50 \%, 4=51$ to $75 \%, 5=76$ to $93 \%$, and $6=94$ to $100 \%$ of the root surface with lesions. Each point represents the average of three replications in each of three trials, four to five carrots per replication. $R^{2}$ values for the $20,25,30$, and $35^{\circ} \mathrm{C}$ treatments were 0.16 , $0.30,0.38$, and 0.49 , respectively.
Effect of temperature and soil saturation duration on soft rot caused by $E$. chrysanthemi. Temperature and duration of saturation significantly affected soft rot severity (Fig. 1). Little disease occurred during the first $24 \mathrm{~h}$, regardless of temperature. After $24 \mathrm{~h}$, the severity of rot increased with increasing temperature and duration of saturation. At 96 h, $75 \%$ of the surface area of carrots in the $35^{\circ} \mathrm{C}$ water bath was rotted, whereas only $7 \%$ was rotted in the $20^{\circ} \mathrm{C}$ water bath. There was a positive linear relationship between disease severity and duration of saturation for each temperature. Slopes of the regression lines at 35 and $30^{\circ} \mathrm{C}$ and slopes at 25 and $20^{\circ} \mathrm{C}$ were significantly different $(P=0.02$ and 0.04 , respectively). Slopes of the regression lines at 30 and $25^{\circ} \mathrm{C}$ were not significantly different $(P=0.69)$. Neither control treatment (saturated with water but not inoculated and inoculated but not saturated with water) developed soft rot.

Temperature and duration of saturation also significantly affected soft rot incidence (Fig. 2). There were no soft rot lesions on carrots that had been held in soil saturated for 12 and $24 \mathrm{~h}$ at 20 and $25^{\circ} \mathrm{C}$ or for $12 \mathrm{~h}$ at $30^{\circ} \mathrm{C}$. After $24 \mathrm{~h}$, incidence continued to increase up to $72 \mathrm{~h}$ at $35^{\circ} \mathrm{C}$ and up to $96 \mathrm{~h}$ at all other temperatures. At $96 \mathrm{~h}, 94 \%$ of the carrots had lesions in the $30^{\circ} \mathrm{C}$ water bath, whereas the incidence was $45 \%$ in the $20^{\circ} \mathrm{C}$ water bath. There was a positive linear relationship between disease incidence and duration of saturation for each temperature. Slopes of the lines for the different temperatures were significantly different $(P=0.001)$.

Comparison of soft rot ability. Bacterial species and temperature significantly affected the amount of carrot tissue consumed by the bacteria. E. chrysanthemi caused a greater loss of carrot tissue at higher temperatures than E. carotovora subsp. carotovora (Fig. 3). Although water-soaked areas were observed on disks inoculated with $E$. carotovora subsp. carotovora, neither bacterium reduced carrot disk weight at $15^{\circ} \mathrm{C}$. In general, both bacteria caused moderate carrot weight reduction at 20 and $25^{\circ} \mathrm{C}$. The greatest weight loss of carrot tissue was caused by E. chrysanthemi at $35^{\circ} \mathrm{C}$. E. carotovora subsp. carotovora isolates were relatively less virulent than E. chrysanthemi at the higher temperatures. None of the E. carotovora subsp. carotovora isolates reduced carrot disk weight at $35^{\circ} \mathrm{C}$. No weight loss of the noninoculated disks occurred at any temperature.

\section{DISCUSSION}

Although E. chrysanthemi was reported on carrot in Texas and Taiwan $(7,16)$, this is the first report of E. chrysanthemi causing soft rot of carrot in California. In this study, E. chrysanthemi caused soft rot craters at temperatures from 20 to $35^{\circ} \mathrm{C}$ and the development of soft rot increased as 
temperature increased. Although E. carotovora subsp. carotovora is also capable of soft rotting carrots, E. chrysanthemi caused soft rot at higher temperatures. Our results are consistent with Lauritzen (9), who found that E. carotovora rotted carrots at $24^{\circ} \mathrm{C}$ but not at higher temperatures. Similar trends have been reported for soft rots on other hosts. Witloof chicory soft rot caused by E. carotovora subsp. carotovora was severe at 30 but not $35^{\circ} \mathrm{C} \mathrm{(13).} \mathrm{Soft} \mathrm{rot}$ of Phillodendron selloum caused by $E$. chrysanthemi was most severe at 28 to $34^{\circ} \mathrm{C}$ (5). E. chrysanthemi caused more severe soft rot of potatoes at 30 and $35^{\circ} \mathrm{C}$ than E. carotovora subsp. carotovora (8). Although soft rot of carrot caused by $E$. carotovora subsp. carotovora occurs consistently at a low incidence in California fields, it is usually associated with poorly drained areas in a field or near sprinkler system leaks (J. Nunez, personal observation). The relatively high soil temperatures in California carrot fields in the late summer of 1998 may explain why E. chrysanthemi, and not E. carotovora subsp. carotovora, resulted in significant economic losses. Experimental temperatures were selected to bracket the soil temperatures recorded at the Shafter Research Station, located in the heart of carrot production in the San Joaquin Valley. Maximum daily soil temperatures, recorded at a depth of 15 $\mathrm{cm}$ under irrigated grass, were 23.3 to $31.7^{\circ} \mathrm{C}$ during August and September 1998. High temperatures and consequent irrigations apparently triggered the carrot soft rot epidemic, in which truckloads of

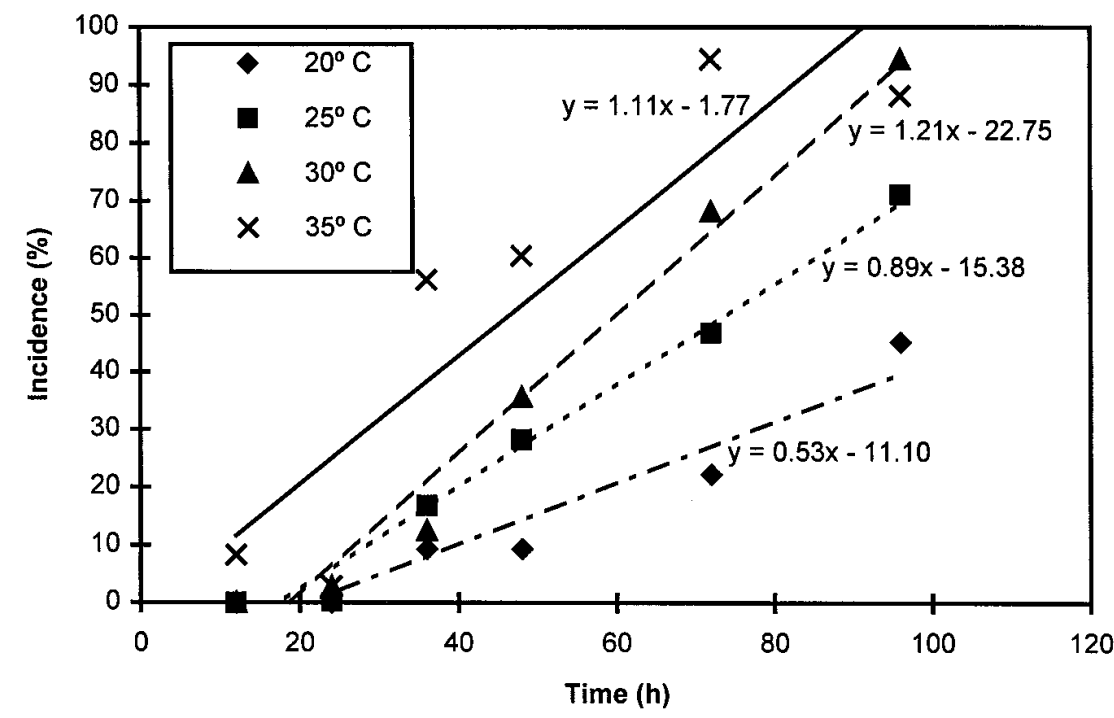

Fig. 2. Influence of temperature and duration of soil saturation on incidence of carrot soft rot. Carrots were grown in 11-cm-diameter styrofoam cups and were 10 to $12 \mathrm{~cm}$ long and 1.5 to $2 \mathrm{~cm}$ wide at the shoulder when inoculated. Each point represents the average of three replications in each of three trials, four to five carrots per replication. $R^{2}$ values for the $20,25,30$, and $35^{\circ} \mathrm{C}$ treatments were 0.23 , $0.40,0.66$, and 0.55 , respectively.

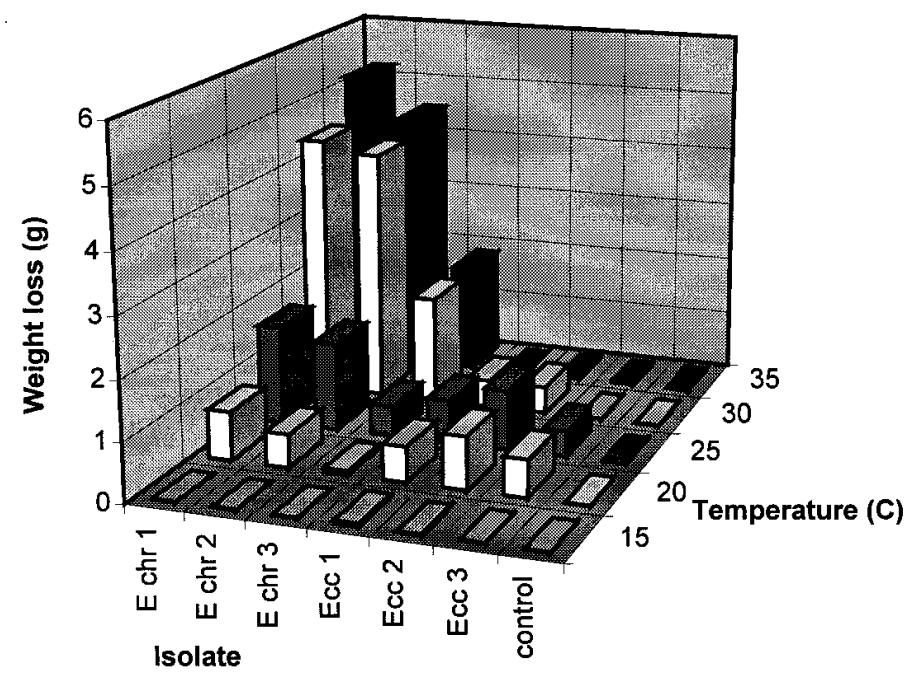

Fig. 3. Reduction of carrot disk weight by three isolates each of Erwinia chrysanthemi (E chr) and $E$. carotovora subsp. carotovora (Ecc) at five temperatures for $48 \mathrm{~h}$. Controls were sterile water. harvested carrots and several fields were abandoned.

The origin of the inoculum of E. chrysanthemi in the carrot fields is not known. Potatoes and onions, which are among the crops grown in rotation with carrots in the San Joaquin Valley, are also hosts and may maintain soil populations of E. chrysanthemi (3). E. chrysanthemi has previously been isolated from potatoes grown in Kern County (R. M. Davis, personal observation). E. chrysanthemi may also occur in irrigation water. Although E. chrysanthemi was not found in a survey of surface water in North America, E. carotovora subsp. carotovora was isolated at high frequency (6).

In our experiments, soil saturation was used to ensure a constant film of water surrounding each carrot, which was necessary for disease development. Under California conditions, carrots are typically irrigated by solid set sprinklers every 7 to 10 days for 10 to $12 \mathrm{~h}$. However, irrigation events may be more frequent and for longer duration during very hot or windy conditions. Thus, irrigation may result in a film of water around the carrot root for extended time periods, especially in poorly drained soils. In potato, a film of water surrounding the tuber for $2.5 \mathrm{~h}$ at $22^{\circ} \mathrm{C}$ causes tissues within the tuber to become anaerobic, an important predisposing factor for blackleg development $(1,11)$. Oxygen stress may also be a necessary predisposing factor in soft rot of carrot. This may account for the lack of soft rot in the controls that were inoculated but not saturated with water. Based on these results, growers should limit the length of time carrot roots are surrounded by a film of water, especially at high soil temperatures.

\section{LITERATURE CITED}

1. Aleck, J. R., and Harrison, M. D. 1978. The influence of inoculum density and environment on the development of potato blackleg. Am. Potato J. 55:479-494.

2. Choi, J. E., Han, K. S., and Yu, S. J. 1989. Identification of bacteria causing soft rot disease of carrot. Kor. J. Plant Pathol. 5:349-353.

3. Dickey, R. S. 1979. Erwinia chrysanthemi: a comparative study of phenotypic properties of strains from several hosts and other Erwinia species. Phytopathology 69:324-329.

4. Dickey, R. S., and Kelman, A. 1988. Erwinia, 'Carotovora' or soft rot group. Pages 44-59 in: Laboratory Guide for the Identification of Plant Pathogenic Bacteria, 2nd ed. N. W. Schaad, ed. APS Press, St. Paul, MN.

5. Haygood, R. A., and Strider, D. L. 1979. Influence of temperature, inoculum concentration, and wounding on infection of Philodendron selloum by Erwinia chrysanthemi. Plant Dis. Rep. 63:578-580.

6. Harrison, M. D., Franc, G. D., Maddox, D. A., Michaud, J. E., and McCarter-Zorner, N. J. 1987. Presence of Erwinia carotovora in surface water in North America. J. Appl. Bacteriol. 62:565-570.

7. Hsu, S.-T., and Tzeng, K.-C. 1982. Species of Erwinia associated with soft rot disease of plant in Taiwan. Pages 9-18 in: Proc. Fifth Int. Conf. Plant Pathogenic Bacteria. J. C. Lozano ed. CIAT, Cali, Columbia. 
8. Jabuonski, R. E., Reifschneider, F. J. B., and Takatsu, A. 1988. The influence of temperature on damage caused by Erwinia spp. in potato tubers. Fitopatol. Bras. 13:317-319.

9. Lauritzen, J. I. 1932. Development of certainstorage and transit diseases of carrots. J. Agric. Res. 44:861-912.

10. Miller, T. D., and Schroth, M. N. 1972. Monitoring the epiphytic population of Erwinia amylovora on pear with a selective medium. Phytopathology 62:1175-1182.

11. Perombelon, M. C. M., Lumb, V. M., Zutra,
D., Hyman, L. J., and Burnett, E. M. 1989. Factors affecting potato blackleg development. Pages 421-431 in: Vascular Wilt Diseases of Plants. E. C. Tjamos and C. Beckman, eds. Springer-Verlag, Berlin.

12. Ramesh, C., Ram, K., Chand, R., and Kishun, R. 1989. Studies of soft rot of carrot. Indian Phytopathol. 42:137-139.

13. Schober, B. M., and Zadoks, J. C. 1999. Water and temperature relations of softrot bacteria: growth and disease development. Ann. Appl. Biol. 134:59-64
14. Segall, R. H., and Dow, A. T. 1973. Effects of bacterial contamination and refrigerated storage on bacterial soft rot of carrots. Plant Dis. Rep. 57:896-899.

15. Suslow, T. V., Schroth, M. N., and Isaka, M 1982. Application of a rapid method for gram differentiation of plant pathogenic and saprophytic bacteria without staining. Phytopathology 72:917-918.

16. Towner, D. B., and Berha, L. 1976. Core-rot: a bacterial disease of carrots. Plant Dis. Rep. 60:357-359. 